\title{
FAKTOR-FAKTOR PENYEBAB KETERABAIAN HAK-HAK ANAK PASCAPERCERAIAN
}

\author{
Oxsis Mardi, Fatmariza Fatmariza \\ Universitas Negeri Padang, Padang \\ oxsismardi@gmail.com
}

\begin{abstract}
Abstrak
Penelitian ini bertujuan untuk mendeskripsikan faktor-faktor penyebab penelantaran hak-hak anak pada keluarga yang bercerai di Kecamatan Lubuk Begalung Kota Padang. Penelitian ini dilatarbelakangi oleh permasalah mengenai penelantaran hak-hak anak yang ditemukan di Kecamatan Lubuk Begalung Kota Padang. Jenis penelitian ini adalah penelitian kualitatif yang dilakukan di Kecamatan Lubuk Begalung Kota Padang. Kebaharuan dari penelitian ini adalah belum adanya penelitian tentang faktor keterabaian hak-hak anak pasca putusan cerai yang ada di Kota Padang. Hasil penelitian menunjukkan tiga hal, yaitu: alasan orang tua menelantarkan hak-hak anak pada keluarga yang bercerai di Kecamatan Lubuk Begalung Kota Padang disebabkan karena suami kebanyakan berpenghasilan kecil dan tidak memiliki pekerjaan yang tetap sehingga dalam melaksanakan kewajibanya berupa pemenuhan hak-hak anak; Berdasarkan hasil penelitian, dapat disimpulkan bahwa penelantaran hak-hak anak disebabkan oleh faktor ekonomi sehingga berdampak pada psikologis anak sehingga diperlukan peran optimal dari pengadilan agama, BP4, keluarga, dan masyarakat dalam mengentaskan permasalahan tersebut.
\end{abstract}

Kata kunci : Perlindungan; Hak Anak; Perceraian. 


\title{
FACTORS CAUSING IMPOSSIBILITY OF THE RIGHTS OF THE POST-DIRECTION CHILDREN
}

\begin{abstract}
This study aims to describe the factors that cause neglect of children's rights in divorced families in Lubuk Begalung District, Padang City. This research is motivated by problems regarding neglect of children's rights found in Lubuk Begalung District, Padang City. This type of research is a qualitative research conducted in Lubuk Begalung District, Padang City. The novelty of this research is that there is no research on the factor of ne glect of children's rights after the divorce decision in the city of Padang. The results showed three things, namely: the reason why parents neglect children's rights to divorced families in Lubuk Begalung District, Padang City is becausehusbands mostly earn little and do not have permanent jobs so that in carrying out their obligations in the form of fulfilling children's rights; Based on the results of the research, it can be concluded that neglect of children's rights is caused by economic factors that have an impact on children's psychology so that an optimal role is needed from the religious court, $B P 4$, family and society in alleviating these problems.
\end{abstract}

Keywords: Protection; Children's Rights; Divorce. 


\section{PENDAHULUAN}

\section{A. Latar Belakang}

Semakin majunya perkembangan ilmu dan teknologi dan dampak dari globalisasi dunia akan memberikan dampak bagi peradaban manusia. Dampak negatif yang timbul antara lain kenakalan remaja, penyalahgunaan narkotika, penyimpangan orientasi seksual, pergaulan bebas dan pernikahan dini. Pada akhrnya dampak negatif tersebut akan masuk pada tatanan keluaga. Adanya kekerasan dalam rumah tangga, kekerasan terhadap anak-anak, dan tingginya angka perceraian. ${ }^{1}$ Pasangan suami istri ketika masih dalam tahap adaptasi masingmasing masih memiliki rasa ego, sehingga diperlukan komunikasi dan komitmen yang kuat bagi pasangan suami istri. Ketika ego dari masing-maing pihak tidak ada yang mengalah dan hubungan komunikasi yang tidak harmonis maka akan terjadi perceraian. ${ }^{2}$ Hal ini terbukti dengan tingginya angka perceraian yang terjadi di masyarakat. Perkawinan idealnya sebagai upaya dalam membentuk keluarga harmonis dan dipenuhi rasa kasih sayang malah berakibat adanya kekerasan dalam rumah tangga dan berakhir dengan perceraian. ${ }^{3}$

Data dari Kementerian Agama Sumatera Barat mencatat adanya 18.270 kasus perceraian yang terjadi mulai dari tahun 2013 sampai dengan tahun 2015. Angka perceraian yang paling tinggi berada di Kota Padang sebanyak 3.058 kasus, sedangkan angka perceraian terendah berada di Kabupaten Pesisir Selatan sebanyak 467 kasus. Penyebab tingginya angka perceraian dalam 3 tahun terakhir ini yang paling banyak menjadi faktor penyebab perceraian adalah faktor ekonomi. Kepala Badan Penasihatan dan Pelestarian Perkawinan (BP4) Provinsi Sumatera Barat, Damri Tanjung mengatakan Tingkat perceraian di Provinsi Sumatera Barat melampaui Skala Nasional yakni 13,8\%. Untuk Skala Nasional tingkat perceraian

\footnotetext{
${ }^{1}$ Siti Chadijah, “Karakteristik Keluarga Sakinah Dalam Islam”, Jurnal Rausyan Fikr 14 (1), 2018, hal 113. DOI: http://dx.doi.org/10.31000/rf.v14i1.676

${ }^{2}$ Urip Tri Wijayanti, "Analisis Faktor Penyebab Perceraian Pada Masa Pandemi Covid19 Di Kabupaten Banyumas”, Jurnal Ilmu Keluarga dan Konsumen 14 (1), 2021, 14-26. DOI: https://doi.org/10.24156/jikk.2021.14.1.14

${ }^{3}$ Maisah, "Rumah Tangga dan Ham: Studi atas Trend Kekerasan dalam Rumah Tangga di Provinsi Jambi”, Jurnal Musawa 15 (1), 2016, hal 125-128. DOI: https://doi.org/10.14421/musawa.2016.151.125-128
} 
berada pada kisaran 11\%. Pada tahun 2017 terjadi peningkatan angka perceraian yang mencapai 1.610 kasus. Tingginya angka perceraian tersebut banyak disumbang oleh perceraian di Kota Padang yang mencapai 1.823 kasus. Data pada tahun 2019 kasus perceraian di Kota Padang mencapai 1765 kasus. Tingginya angka perceraian di Kota Padang banyak disumbang oleh perceraian yang terjadi di Kecamatan Koto Tangah dan Kecamatan Lubuk Begalung.

Dari data awal yang diperoleh dalam penelitian ini menemukan bahwa masih banyak anak yang terlantar dan tidak mendapatkan hak-haknya sebagai seorang anak. Selain itu, hasil wawancara dengan Kepala Badan Penasihatan dan Pelestarian Perkawinan (BP4) Provinsi Sumatera Barat, Damri Tanjung menunjukkan bahwa ada lima kasus yang cenderung terjadi pada anak pasca perceraian orang tua. Berdasarkan hasil wawancara tidak terstruktur dengan beberapa orang narasumber di daerah Lubuk Begalung, padang pada tanggal 15 hingga 21 Desember 2017, maka dapat dipahami bahwa perceraian yang terjadi pada keluarga sering berpengaruh terhadap perilaku anak sehingga kecenderungan yang terjadi adalah anak bermasalah dalam pendidikan dan putus sekolah di usia wajib belajar. Narasumber menuturkan bahwa faktor ekonomi menyebabkan banyaknya anak bermasalah dengan keluarga dan guru di sekolah. Selain itu, narasumber menambahkan bahwa terdapat lima masalah penting yang terjadi pasca perceraian. Salah satu dampak yang sering terjadi dalam kasus perceraian adalah hak-hak anak yang tidak diberikan. Hal tersebut dibuktikan dengan banyaknya penelitian mengenai perlindungan hak-hak anak mengenai hak pemberian nafkah anak pascaperceraian telah banyak dimuat pada jurnal-jurnal hukum.

Sudah ada beberapa penelitian sebelumnya sebelumnya yang relevan dengan penelitian ini diantaranya penelitian oleh Stepani (2015), pada penelitian nya tersebut Stepani mengkaji tentang hak yang dapat diperoleh anak pasca putusan cerai dan bagaimana kewajiban dari orang tua pasca putusan cerai. Penelitian tersebut berlokasi di Provinsi Sulawesi Utara. Walaupun hak-hak anak sudah terlindungi tetapi pada implementasinya masih ada hak-hak anak yang terabaikan. Setelah putusan cerai ditetapkan oleh pengadilan orang tua juga masih mempunyai kewajiban dan tanggung jawab terhadap anak-anaknya, tetapi pada penelitian 
tersebut masih ditemukan penyimpangan yang terjadi dalam kewajiban dan tanggungang jawab orang tua terhadap anak-anaknya. ${ }^{4}$

Penelitian serupa juga diteliti oleh Salma dan Djalal (2017) melakukan penelitian tentang "Perlindungan Hukum bagi Perempuan dan Anak (Analisis Putusan Hakim tentang Nafkah Madhiyah pada Pengadilan Agama di Sumatera Barat)". Penelitian tersebut lebih fokus mengkaji penyebab terjadinya perbedaanperbedaan putusan hakim di seluruh pengadilan agama Sumatera Barat tentang nafkah madhiyah. Bagaimana akibat dari perbedaan putusan tersebut menyebabkan terabainya hak-hak isteri dan anak. terhadap nafkah menjadi terabaikan. Ketika isteri meminta haknya berupa nafkah yang kemudian diabaikan oleh suami, hakim pengadilan agama di Sumatera Barat memberikan putusan yang berbeda-beda, ada yang ditolak dan ada yang diterima dengan nominal yang sangat kecil. Hal ini menyebabkan beban yang berat yang harus menjadi tanggungan istri dengan menanggung beban dan biaya hidup anaknya. ${ }^{5}$

Selanjutnya, penelitian mengenai hak anak telah dilakukan Nandang Ihwanudin (2016) yang berjudul "Pemenuhan Kewajiban Pasca Perceraian Di Pengadilan Agama". Penelitian tersebut fokus mengkaji tentang bagaimana suami dalam memenuhi kewajibannya terhadap anak dan istrinya dijalankan dengan sukarela pasca penetapan cerai dari pengadilan agama. Penelitian ini juga mengkaji tentang adanya solusi dalam menerapkan pemberian nafkah tersebut dapat berjalan dengan adil dan memberikan manfaat. ${ }^{6}$

Berdasarkan penelitian yang telah dilakukan oleh penelitian sebelumnya yang relevan dengan penelitian ini, maka terdapat persamaan dan perbedaan. Persamaan penelitian relevan dengan penelitian ini adalah sama-sama meneliti tentang perlindungan hak-hak anak pasca perceraian yang didasarkan pada Undang-

\footnotetext{
${ }^{4}$ Stepani, "Pemenuhan Hak Anak Pasca Perceraian (Studi Kasus Di Sulawesi Utara", Lex et Societatis 3 (3), 2015, hal 116-123.

${ }^{5}$ Salma, Elfia dan Afifah Djalal, "Perlindungan Hukum bagi Perempuan dan Anak (Analisis Putusan Hakim tentang Nafkah Madhiyah pada Pengadilan Agama di Sumatera Barat", Istinbath Journal of Islamic Law 16 (1), 2017, hal 168-208. DOI: https://doi.org/10.20414/ijhi.v16i1.77

6 Nandang Ihwanudin, "Pemenuhan Kewajiban Pasca Perceraian Di Pengadilan Agama”, Jurnal Adliya 10 (1), 2016, hal 51-68. DOI :10.15575/adliya.v10i1.5146
} 
Undang Perlindungan Anak. Perbedaan penelitian-penelitian di atas dengan penelitian ini adalah pada rumusan masalah. Penelitian ini diorientasikan pada permasalahan yang lebih kompleks, yaitu persoalan perlindungan hak-hak anak yang mencakup banyak hal, seperti: hak mendapat kasih sayang, hak mendapat pendidikan, hak kesehatan, dan lain-lain sehingga dapat direkomendasikan sebagai pertimbangan dan pengawasan bagi pengadilan agama maupun masyarakat untuk dapat memberikan hak-hak anak pasca perceraian secara adil. Penelitian ini bertujuan untuk mendeskripsikan faktor-faktor penyebab penelantaran hak-hak anak pada keluarga yang bercerai di Kecamatan Lubuk Begalung Kota Padang.

\section{B. PERMASALAHAN}

1. Faktor-faktor apakah yang menjadi penyebab penelantaran hak-hak anak pada keluarga yang bercerai di Kecamatan Lubuk Begalung Kota Padang?

\section{METODE PENELITIAN}

Jenis penelitian ini adalah penelitian kualitatif dengan menggunakan tipe studi kasus yang bersifat deskriptif. Lokasi penelitian dalam penelitian ini adalah di Kecamatan Lubuk Begalung Kota Padang. Sumber data penelitian ini didapatkan dari hasil wawancara dengan narasumber. Narasumber dalam penelitian ini ditentukan secara purposive sampling. Narasumber penelitian ini berasal dari empat keluarga di Kecamatan Lubuk Begalung Kota Padang yang mengalami perceraian. Teknik pengumpulan data yang digunakan dalam penelitian ini di antaranya: teknik observasi langsung, wawancara, dan dokumentasi. Data yang telah dikumpulkan kemudian dianalisis dengan menggunakan teknik pengabsahan data secara triangulasi. Selanjutnya, tahapan dalam penganalisisan data yang telah diabsahkan, yaitu: tahap reduksi data, penyajian data, dan penarikan simpulan.

\section{PEMBAHASAN}

Memiliki sebuah keluarga sakinah adalah idaman setiap keluarga, untuk mewujudkan suatu keluarga sakinah baukan merupakan suatu hal yang mudah, terdapat halangan dan rintangan dalam menuju proses keluarga yang sakinah. Hambatan dan godaan yang muncul sesuai denganperkembangan zaman dan tekhnologi adalah salah satu tantangan dalam mewujudkan kelaurag yang sakinah saat ini. Kunci dari terbentuknya keluarga sakinah adalah dengan tetap menerapkan 
nilai-nilai ajaran agama, budi pekerti yang luhur dan norma yang berlaku di masyarakat. $^{7}$

Setiap pasanagan suami istri pasti mempunyai masalaha dalam kehidupan pribadi dan rumah tangganya, semuanya tergantung dari bagaimana setiap suami istri dapat menyelesaikan permasalahan tersebut. Perselisihan dalam rumah tangga jika terus dibiarkan akan menimbulkan rasa permusuhan dan akan berakhir dengan perceraian. Perceraian diantara suami istri akan dimulai dengan adanya konflikkonflik kecil sehingga menimbulkan ketidakharmonisan dalam berumah tangga. ${ }^{8}$ Sedangkan dari data penelitian yang dilakukan oleh Ernawati dan Ritta Setiyati (2016) menyebutkan bahwa ada beberapa faktor yang menyebabkan perceraian antara lain perjodohan, ekonomi, dan perselisihan dalam rumah tangga serta adanya orang ketiga. ${ }^{9}$

Data dari penelitian mengenai faktor penyebab keterabaian hak anak pada keluarga yang bercerai di Kecamatan Lubuk Begalung Kota Padang, dari hasil wawancara dengan narasumber menunjukkan faktor penyebab orang tua mengabaikan hak anak yang seharusnya mereka dapatkan menurut UndangUndang Perlindungan Anak dalam pasal 14 ayat 1 No 35 Tahun 2014, seperti berhak untuk di lindungi, berhak untuk mendapatkan pendidikan dari orang tuanya, berhak untuk tumbuh kembang, berhak untuk mendapatkan pembiayaan serta memperoleh hak lainya. Ada beberapa faktor yang menyebabkan terabainya hakhak anak pasca putusan cerai antara lain :

1. Faktor Pekerjaan (Ekonomi)

Dalam membangun sebuah rumah tangga, masing-masing suami dan isteri mempunyai hak dan kewajiban. Kewajiban suami terhadap isterinya antara lain memberi nafkah lahir dan batin, tetapi pada pelaksanaannya tidak adanya tanggung

${ }^{7}$ Farah Chalida Hanoum, "Implementasi Agama dalam Mewujudkan Keluarga Sakinah”, AS-SYAR'I: Jurnal Bimbingan \& Konseling Keluarga 1 (1), 2019, hal 58-75.

DOI https://doi.org/10.47467/as.v1i1.48

8 Andi Kasmawati, Sumarni B, Bakhtiar, "Faktor Penyebab Perceraian Di Kota Makassar (Studi Pada Kantor Pengadilan Agama Klas I A Makassar)”, Jurnal Supremasi 11 (1), 2016, hal 37-46. 10.26858/supremasi.v1 1i1.10025

${ }^{9}$ Ernawati dan Ritta Setiyati, "Pandangan Masyarakat Minangkabau Di Nagari Ulakan Terhadap Perceraian Di Pengadilan Agama", Jurnal Lex Jurnalica 13 (3), 2016, hal 209-222. 
jawab dari suami dalam meberikan nafkah kepada istri yang salah satunya karena tidak adanya pekerjaan yang cukup memadai. Hal ini pula yang menjadi salah satu penyebab dari gugatan cerai yang diajukan oleh istri. ${ }^{10}$

Berdasarkan hasil wawancara dengan salah seorang mantan suami yang telah bercerai yang bernama Beni Agus Syafria di Pengambiran, dapat dijelaskan bahwa alasan tidak terpenuhinya hak anak pasca perceraian adalah faktor ekonomi. Beni Agus Syafria merupakan seorang yang berprofesi sebagai supir angkutan kota di Padang yang tidak memiliki penghasilan tetap karena hanya menjadi supir pengganti. Ia menuturkan bahwa karena tidak memiliki kecukupan penghasilan sehingga tidak dapat memberikan uang bulanan kepada anaknya. Selanjutnya, narasumber mengatakan bahwa biasanya ia hanya bisa memberi uang jajan Rp5.000 atau Rp10.000 kepada anaknya.

Selanjutnya, hasil wawancara dengan Robby Rulence di Cengkeh menunjukkan bahwa faktor ekonomi, khususnya pekerjaan menjadi alasan utama tidak terpenuhinya hak nafkah anak atas suami yang telah bercerai. Narasumber menyatakan bahwa ia memiliki pekerjaan sebagai seorang wiraswasta dan tidak memiliki penghasilan yang tetap. Narasumber menambahkan bahwa biasanya ia hanya mampu memberikan kewajiban nafkah berkisar antara 50.000 sampai 150.000 yang ditujukan untuk uang jajan sekolah anaknya. Hal ini diakui oleh narasumber dan menyatakan bahwa besaran kewajban nafkah yang diberikan kepada anaknya pasca bercerai belum mampu mencukupi kebutuhan anaknya. Oleh sebab itu, narasumber secara jujur mengatakan kepada anak bahwa kondisinya belum bisa sepenuhnya dalam memberikan kewajiban nafkah kepada anak pascabercerai.

Ruslan seorang narasumber yang beralamat di Cengkeh menuturkan bahwa ia menyadari bahwa pekerjaan yang tidak tetap membuat ia tidak dapat memenuhi kebutuhan anaknya pasca bercerai. Narasumber menambahkan bahwa ia sekarang tinggal bersama orang tuanya dan tidak dapat berbuat banyak untuk melaksanakan

10 Wahyu Sururie, Harry Yuniardi, "Perceraian Dalam Keluarga Muslim Di Jawa Barat”, Jurnal Al Manahij 12 (2), 2018, hal 268.

DOI https://doi.org/10.24090/mnh.v12i2.1361 
kewajiban sebagai seorang ayah berupa pemenuhan hak nafkah kepada anaknya. Selain itu, beberapa kali ia telah memberikan uang jajan kepada anaknya dengan kisaran Rp20.000 dan kalau ada rezeki lebih ia dapat memberikan mainan kepada anaknya.

Ketika memasuki bahtera rumah tangga, akan menimbulkan beban dan tanggung jawab yang baru bagisetiap pasangan suami istri. Suami mempunayi kewajiban memberikan nafkah terhadap keluarganya dan istri berkewajiban mengurus rumah tangga dan mengasuh anak-anak. Ketika timbul permasalahan ekonomi akan dapat menimbulkan rasa tidak nyaman dari istri terhadap suami. Jika keadaan ini dibiarkan akan membuat perselisihan di antara mereka. ${ }^{11}$

2. Faktor Komunikasi

Faktor komunikasi merupakan faktor yang dapat mempengaruhi pemenuhan hak nafkah terhadap anak. Disharmonisasi hubungan suami dengan istri yang telah bercerai berdampak kepada anak. Seorang kerabat/ keluarga dekat yang bernama Patma tanggal 2 Januari 2019 di rumahnya menuturkan bahwa narasumber merupakan keluarga dari pihak istri yang telah merawat dari proses perceraian. Artinya, anak menetap di rumah narasumber karena telah bercerai. Narasumber mengetahui bahwa alasan perceraian antara orang tua anak dikarenakan ayahnya tidak bekerja dan sering terjadi perselisihan sehingga perceraian tidak bisa dihindarkan. Narasumber menambahkan bahwa untuk memenuhi kebutuhan anak belum dipenuhi oleh Aaahnya dan hanya beberapa kali orang tua memberi jajan.

Selanjutnya, Patma menuturkan bahwa sudah 6 tahun tidak terdengar kabar keberadaan ayah si anak. Hal tersebut menyebabkan anak tidak mendapat hak nafkah dari ayahnya. Ia menuturkan terkahir kali ayah si anak datang ke rumah memberikan hak nafkah kepada anak terjadi perselisihan dengan istri karena uang yang diberikan belum cukup memenuhi kebutuhan anak. Hal tersebut berdampak

11 Afgan Nugraha, Amiruddin Barinong \& Zainuddin, "Faktor Penyebab Terjadinya Perceraian Rumah Tangga AKibat Perselingkuhan”, Vol. 2 No. 1 (2020): Kalabbirang Law Journal 2 (1), 2021, hal 53-68. DOI : https://doi.org/10.35877/454RI.kalabbirang30 
kepada hubungan keduanya dan sampai 5 tahun ayah si anak tidak lagi mengunjungi dan memberikan uang nafkah kepada anak.

Mantan suami diduga telah melakukan penelantaran hak berupa nafkah kepada anak sehinga belum memenuhi kebutuhan anak. Padahal, anak sangat membutuhkan keperluan-keperluan, seperti: uang sekolah, makan, berobat, dan pakaian-pakaian. Selain itu, narasumber menuturkan bahwa biasanya wali menanggulangi kebutuhan-kebutuhan anak karena mendapat penghasilan dari menjual barang dagangan. Hasil wawancara juga menunjukkan bahwa penelantaran hak berupa nafkah anak oleh orang tua pascabercerai dapat berdampak secara psikologis bagi anak. Narasumber mengatakan bahwa tidak terpenuhinya kebutuhan anak berdampak tidak baik bagi tumbuh kembang anak sehingga sering termenung dan tidak beraktivitas.

Dari penelitian yang dilakukan Bernhardt Siburian (2017) menyebutkan bahwa komunikasi yang kurang menyebabkan terjadinya perselisihan dalam keluarga. Adanya salah satu pihak dari pasanagan suami istri yang mengajukan gugatan cerai karena adanya perselisihan dan pertengkaran dalam rumah tangga. Tidak terjalinya komunikasi yang baik antar pasangan suami istri menyebabkan setiap perselisihan dan pertengkaran tidak dapat terselesaikan dengan baik dan pada akhirnya berujung pada gugatan cerai. ${ }^{12}$

Selanjutnya hasil wawancara dengan salah seorang kerabat dekat anak yang bernama Desi di rumahnya di Piai Bawah, Lubuk Begalung menunjukkan bahwa ayah si anak tidak lagi memberikan hak nafkah kepada anak selama 3 tahun karena telah pindah ke Jati. Narasumber merupakan wali kerabat dekat dari pihak istri dan telah mengetahui perceraian yang dialami oleh kerabatnya. Narasumber mengetahui bahwa alasan penelantaran hak nafkah anak terjadi karena sering terjadinya pertengkaran antara orang tua yang bercerai. Selain itu, pertengkaran tersebut sering dipicu oleh masalah komunikasi. Mantan suami dari kerabatnya

12 Bernhardt Siburian, "Analisis Faktor-Faktor Penyebab Perceraian Berdasarkan Keputusan Pengadilan Negeri Balige Tahun 2017”, JIREH-Jurnal Ilmiah Religiosity Entity Humanity 1 (1), 2019, hal 31-39. DOI: https://doi.org/10.37364/jireh.v1i1.5 
belum memiliki penghasilan yang tetap dan sering tidak memberikan hak nafkah kepada anak sehingga terjadilah pertengkaran tersebut.

Narasumber mengetahui bahwa anak belum mendapat nafkah untuk memenuhi kebutuhannya dari orang tua pasca bercerai namun hanya bisa pasrah. Ia menambahkan bahwa anak sangat membutuhkan keperluan-keperluan, seperti: makan, biaya sekolah, membeli buku dan baju, serta berobat. Menurut narasumber, belum ada usaha yang dilakukan pihak keluarga jika anak tidak mendapat nafkah dari orang tuanya. Keluarga hanya menjalani kehidupan seperti apa adanya tidak melakukan penuntutan kepada orang tua anak dalam mendapatkan hak nafkah. Bahkan, narasumber juga menyatakan bahwa pihak keluarga mengetahui bahwa penelantaran hak anafkah anak berdampak terhadap anak jika nafkah dari orang tua pascabercerai tidak diberikan. Dampat tersebut berupa dampak psikologis, yaitu anak jadi sering murung dan mengeluh.

3. Faktor Kurangnya Kesadaran dan Tanggung Jawab

Faktor tidak ada tanggungjawab adalah "perbuatan yang membiarkan pasangan dan anggota lainnya dalam keadaan tidak dipelihara". Dalam praktiknya di pengadilan agama, tidak ada tanggung jawab disebabkan salah satu pihak terutama suami meninggalkan isteri tanpa alasan yang jelas, tidak memberi nafkah kepada isteri seperti pada putusan Pengadilan Agama Bogor Nomor 446/Pdt.G/2011/ PA.Bgr, dan putusan Pengadilan Agama Garut Nomor 64/Pdt.G/2015/PA.Grt tentang ketiadaan tanggungjawab suami di dalam memberi nafkah. ${ }^{13}$

Faktor yang dapat memicu terjadinya penelantaran hak nafkah anak adalah faktor kurangnya kesadaran dan tanggung jawab ayah. Beberapa kasus yang ditemukan di Lubuk Begalung menunjukkan bahwa terdapat faktor rendahnya kesadaran dan tanggung jawab ayah dalam memenuhi kebutuhan anaknya. Ayah berdalih bahwa ia juga menanggung biaya keseharian karena telah menikah dan mempunyai anak dari hasil pernikahan yang kedua. Hal tersebut berdampak pada pemenuhan hak nafkah anak dari hasil pernikahan yang pertama.

${ }^{13}$ Op. Cit Wahyu Sururie, hal 271. 
Kasus pertama mengenai kurangnya kesadaran dan tanggung jawab mantan suami terhadap pemenuhan hak nafkah anak terjadi di Piai Bawah Lubuk Begalung. Salah seorang kerabat dekat anak yang bernama Roslaini menuturkan bahwa ayah si anak tidak pernah memberikan hak nafkah untuk memenuhi kebutuhankebutuhan anak karena ayahnya telah menikah kembali tiga bulan setelah perceraian terjadi. Narasumber menuturkan bahwa ayah si anak masih tinggal di Padang dan seharusnya masih dapat mengunjungi anaknya untuk memberikan hak nafkah. Hal ini menunjukkan bahwa kurangnya rasa tanggung jawab dan kesadaran mantan suami padahal pemenuhan hak nafkah kepada anak pascabercerai merupakan suatu kewajiban sebagai seorang ayah. Padahal, anak sangat membutuhkan keperluan-keperluan, seperti: uang sekolah, makan, berobat, dan pakaian-pakaian. Selain itu, narasumber menuturkan bahwa biasanya wali menanggulangi kebutuhan-kebutuhan anak karena mendapat penghasilan dari menjual barang dagangan.

Hal serupa terjadi di Sungai Beremas seperti yang dituturkan oleh Yeni Tata. Ia menuturkan bahwa anaknya tidak mendapat hak nafkah dari mantan suaminya. Narasumber menambahkan bahwa mantan suaminya telah menikah lagi sehingga beralasan tidak mampu memberikan uang atau nafkah untuk memenuhi kebutuhankebutuhan anaknya. Narasumber menyatakan bahwa mantan suami memiliki pekerjaan tidak tetap dan kesulitan untuk menanggung dua biaya dari pernikahannya. Namun, narasumber mengatakan walaupun mantan suaminya telah bekeluarga lagi seharusnya juga masih memberikan hak nafkah kepada anaknya yang pertama. Ia menilai bahwa mantan suaminnya kurang bertanggung jawab padahal sudah ditelepon oleh anak untuk membeli pakaian, uang jajan, dan keperluan sekolah.

Beberapa kasus perceraian yang terjadi di Kecamatan Lubuk Begalung Kota Padang adalah adanya hambatan dalam pemenuhan hak nafkah terhadap anak. Hambatan yang sering dijumpai karena keterbatasan ekonomi dari mantan suami. Penelantaran hak nafkah anak setelah orang tua bercerai merupakan hal yang sangat penting untuk menjamin masa depan anak. Berdasarkan temuan penelitian melalui wawancara dengan narasumber, dapat dijelaskan alasan orang tua menelantarkan 
hak-hak anak pada keluarga yang bercerai di Kecamatan Lubuk Begalung Kota Padang. Informasi yang didapatkan dari hasil wawancara dengan narasumber menunjukkan bahwa kasus-kasus perceraian yang dijalani orang tua disebabkan oleh faktor ekonomi.

Faktor ekonomi mengakibatkan suami istri sering bertengkar, perselisihan, dan bahkan tidak jarang istri juga mendapat perlakuan kekerasan fisik dari mantan suaminya. Selain itu, pada hakikatnya, kekerasan dan perselisihan tersebut merupakan dampak dari status pekerjaan suami yang berpenghasilan tidak tetap dan sebahagian tidak bekerja sehingga tidak mampu memberikan nafkah kepada keluarganya. Seharusnya, perkawinan dibalut dengan rasa harmonis agar tidak terjadi kekerasan dalam rumah tangga dan berakhir dengan perceraian. ${ }^{14}$ Pada hakikatnya, ajaran agama Islam telah mensyariatkan sebuah perkawinan dengan tujuan untuk menjalin rumah tangga yang bahagia secara lahiriah dan batiniah, serta hidup dalam keharmonisan. Akan tetapi, pada kenyataannya tidak semua keluarga hidup dalam keadaan bahagia dan harmonis.

Data menunjukkan bahwa suami kebanyakan berpenghasilan kecil dan tidak memiliki pekerjaan yang tetap. Hal tersebut berdampak besar dalam melaksanakan kewajibanya berupa pemenuhan hak nafkah anak. Namun, pada satu sisi lain, kewajiban seorang ayah dalam memenuhi hak anak tetap melekat demi kelangsungan hidup anaknya. Hasil temuan penelitian menegaskan bahwa terdapat tiga corak suami tidak mampu menafkahi anak-anaknya, yaitu: (1) suami yang menolak untuk melakukan tanggung jawab dalam memberikan nafkah untuk anaknya. Kasus ini sering terjadi terutama ketika suami istri yang telah tinggal terpisah atau mantan suami secara sengaja meninggalkan istri dan anak-anaknya; (2) suami yang lalai dalam menunaikan kewajiban dalam menafkahi anaknya; dan (3) suami yang gagal untuk menunaikan kewajiban dalam menafkahi anaknya. Seorang suami dikatakan gagal dalam menunaikan tanggung jawabnya telah berusaha secara maksimal namun hasil yang didapatkan tidak sesuai dengan yang diharapkannya.

${ }^{14}$ Op.Cit, Maisah 
Menurut peraturan perundang-undangan dan hukum Islam, tanggung jawab biaya nafkah anak setelah terjadinya perceraian pada prinsipnya dibebankan kepada orang tua laki-laki. Dalam Kompilasi Hukum Islam tentang pemeliharaan anak Pasal 104 ayat 1 dinyatakan bahwa "Semua biaya penyusuhan anak dipertanggung jawabkan kepada ayahnya. Apabila ayahnya telah meninggal dunia, maka biaya penyusuhan diberikan kepada orang yang berkewajiban memberi nafkah kepada ayahnya atau walinya". Oleh sebab itu, seorang ayah harus berusaha mencarikan dan memenuhi hak nafkah untuk anaknya karena hal tersebut merupakan suatu kewajiban bagi seorang ayah meski sudah bercerai. Selain itu, pada peraturan yang berlaku seorang ayah juga mempunyai kewajiban-kewajiban, seperti: (1) memberi upah penyusuhan dan pengasuhan atas anaknya, (2) membayar sewa rumah apabila si ibu tidak mempunyai rumah, (3) memenuhi kebutuhan dasar atau pokok anak kecil, seperti makan, minum, tempat tidur, obat-obatan dan kebutuhan dasar lainnya yang memang dibutuhkan oleh anak.

Hasil wawancara dengan narasumber menunjukkan bahwa kesanggupan suami untuk memberikan kewajiban nafkah berkisar antara Rp20.000 sampai Rp400.000/ bulan. Namun kisaran tersebut tidak dipenuhi secara berkelanjutan sehingga istri mengandalkan hasil pendapatannya dari berjualan atau bekerja serta bantuan dari kerabat dekatnya. Biasanya tanggungan suami digunakan untuk keperluan uang jajan sekolah anaknya. Hal ini tentu bertentangan dengan pandangan hukum Islam. Menurut Kompilasi Hukum Islam dalam Pasal 105 yaitu: dalam huruf (c) biaya pemeliharaan ditanggung oleh bapaknya. Oleh sebab itu, dalam hal nafkah tetap menjadi kewajiban seorang ayah walaupun sudah terjadi perceraian. Selain itu, dalam Al-Qur'an Surat Al Baqarah Ayat 233 ditegaskan tentang kewajiban ayah atau orang tua laki-laki untuk menafkahi anaknya.

Selanjutnya, banyak ditemukan pada kasus-kasus perceraian dari pihak suami menikah lagi setelah terjadi perceraian. Hal ini akan mempersulit bagi ayah untuk tetap memberikan hak-hak nafkah anak. Apabila ayah memiliki keluarga baru, tentu dapat berdampak bagi pemenuhan hak anak karena ia harus membiayai keluarganya yang baru. Selain itu, tidak terpenuhinya hak-hak anak oleh ayah dapat disebabkan 
karena istri baru tidak memberikan izin untuk menafkahi anak dari perkawinan yang terdahulu sehingga ayah tidak lagi menjalankan kewajibannya.

Sesuai dengan tuntunan yang diajarkan dalam agama Islam, bahwa untuk membangun sebuah keluarga terhormat tidak perlu harus mempunyai materi yang cukup atau jabatan dan pangkat yang tinggi. Mengingat banyak orang kaya dan mempunyai jabatan yang tinggi tetapi tidak terhormat karena hasil dari kekayaannya berasala dari hasil korupsi. Bahkan keluarga yang mereka bangun, kehormatan dan keharmonisan tidak terwujud. Dalam membentuk sebuah keluarga yang utuh, harmonis dan bahagia cukup dengan memiliki dan menjunjung tinggi nilai-nilai sosial, norma agama dan menerapkannya dalam kehidupan sehari-hari. ${ }^{15}$

Mempersiapkan generasi emas, yang mempuni, cerdas, terampil (mahir) sangat penting bagi orang tua. Karena anak akan membawa martabat dan kemuliaan leluhurnya. Hal ini sesuai dengan pendapat Mawarid (2017) yang menyatakan bahwa "salah satu fungsi dalam keluarga adalah fungsi edukatif. Fungsi ini terkait dengan perannan keluarga dalam memberikan pendidikan kepada anggotanya, terutama kepada anak-anak agar anak-anak tumbuh menjadi anak yang mempunyai budi pekerti luhur. Sehingga keluarga merupakan tempat pendidikan yang paling utama". ${ }^{16}$

Pendidikan agama dan pendidikan umum yang cukup mempunyai peran yang penting dalam membangun sebuah keluarga. Pasangan suami istri yang mempunyai latar belakang pendidikan dan usia yang cukup akan mengantarkan pasangan suami istri menuju perkawinan yang stabil dan tangguh dalam mengelola konflik yang ada dalam perkawinan. Andaikan dalam perkawinan mereka berakhir karena suatu sebab yang menjadi perbedaan diantara mereka. Adanya kesadaran dari mereka akan apa yang menjadi kewajiban akan dipenuhi, sehingga hak-hak anak-anak dan

15 Zainal Arifin, "Tantangan Membentuk Keluarga Sakinah Pada Generasi Milenial”, Jurnal Wahana Islamika 6 (2), 2020, hal 187-211.

DOI https://doi.org/10.5281/wahanaislamika.v6i2.91

${ }^{16}$ Amirah Mawarid, "Pendidikan Pra Nikah; Ikhtiar Membentuk Keluarga Sakinah", Jurnal Tarbawi 2 (2), 2017, hal158-168.

DOI: https://doi.org/10.26618/jtw.v2i02.1036 
istri tidak diabaikan sehingga terjalin hubungan yang harmonis diantara mereka pasca terbitnya putusan perceraian.

\section{PENUTUP}

Berdasarkan hasil pembahasan tersebut dapat disimpulkan tiga hal yang menjadi faktor penyebab perceraian di Kecamatan Lubuk Begalung Kota Padang adalah faktor ekonomi, alasan orang tua menelantarkan hak-hak anak pada keluarga yang bercerai disebabkan oleh faktor ekonomi. Data menunjukkan bahwa suami kebanyakan berpenghasilan kecil dan tidak memiliki pekerjaan yang tetap. Kedua, terdapat dampak-dampak psikologis penelantaran hak-hak terhadap anak pada keluarga yang bercerai di Kecamatan Lubuk Begalung Kota Padang. Banyak anak yang cukup terpukul dan sedih terkait perceraian orang tuanya. Bahkan anak kurang merasakan kasih sayang dari ayahnya setelah orang tuanya bercerai. Ketiga, upaya atau solusi orang tua dalam memberikan hak-hak terhadap anak pada keluarga yang bercerai di Kecamatan Lubuk Begalung Kota Padang adalah istri memutuskan untuk bekerja sendiri dan meminta bantuan pada kerabat dekat. Selain itu, solusi yang dapat direkomendasikan dalam menangani kasus penelantaran hak-hak anak adalah mengoptimalkan peran pengadilan agama dan BP4. 


\section{DAFTAR PUSTAKA}

\section{Buku}

L. Ifadah, (2017), "Diary Book: Sebagai Alat Ungkap Masalah pada Remaja Introvert”, Yogyakarta, Trussmedia.

\section{Jurnal}

Afgan Nugraha, Amiruddin Barinong \& Zainuddin, "Faktor Penyebab Terjadinya Perceraian Rumah Tangga AKibat Perselingkuhan”, Vol. 2 No. 1 (2020): Kalabbirang Law Journal 2 (1), 2021.

DOI : https://doi.org/10.35877/454RI.kalabbirang30

Andi Kasmawati, Sumarni B, Bakhtiar, "Faktor Penyebab Perceraian Di Kota Makassar (Studi Pada Kantor Pengadilan Agama Klas I A Makassar)”, Jurnal Supremasi 11 (1), 2016. 10.26858/supremasi.v11i1.10025

Amirah Mawarid, "Pendidikan Pra Nikah; Ikhtiar Membentuk Keluarga Sakinah”, Jurnal Tarbawi 2 (2), 2017.

DOI: https://doi.org/10.26618/jtw.v2i02.1036

Bernhardt Siburian, "Analisis Faktor-Faktor Penyebab Perceraian Berdasarkan Keputusan Pengadilan Negeri Balige Tahun 2017”, JIREH-Jurnal Ilmiah Religiosity Entity Humanity 1 (1), 2019.

DOI: https://doi.org/10.37364/jireh.v1i1.5

Ernawati dan Ritta Setiyati, "Pandangan Masyarakat Minangkabau Di Nagari Ulakan Terhadap Perceraian Di Pengadilan Agama", Jurnal Lex Jurnalica 13 (3), 2016.

Farah Chalida Hanoum, "Implementasi Agama dalam Mewujudkan Keluarga Sakinah”, AS-SYAR'I: Jurnal Bimbingan \& Konseling Keluarga 1 (1), 2019. DOI https://doi.org/10.47467/as.v1i1.48

Maisah, "Rumah Tangga dan Ham: Studi atas Trend Kekerasan dalam Rumah Tangga di Provinsi Jambi”, Jurnal Musawa 15 (1), 2016.

DOI: https://doi.org/10.14421/musawa.2016.151.125-128

Salma, Elfia dan Afifah Djalal, "Perlindungan Hukum bagi Perempuan dan Anak (Analisis Putusan Hakim tentang Nafkah Madhiyah pada Pengadilan Agama di Sumatera Barat”, Istinbath Journal of Islamic Law 16 (1), 2017. DOI: https://doi.org/10.20414/ijhi.v16i1.77

Siti Chadijah, "Karakteristik Keluarga Sakinah Dalam Islam”, Jurnal Rausyan Fikr 14 (1), 2018. DOI: http://dx.doi.org/10.31000/rf.v14i1.676

Stepani, "Pemenuhan Hak Anak Pasca Perceraian (Studi Kasus Di Sulawesi Utara”, Lex et Societatis 3 (3), 2015.

Urip Tri Wijayanti, "Analisis Faktor Penyebab Perceraian Pada Masa Pandemi Covid-19 Di Kabupaten Banyumas", Jurnal Ilmu Keluarga dan Konsumen 14 (1), 2021. DOI: https://doi.org/10.24156/jikk.2021.14.1.14

Wahyu Sururie, Harry Yuniardi, "Perceraian Dalam Keluarga Muslim Di Jawa Barat", Jurnal Al Manahij 12 (2), 2018.

DOI https://doi.org/10.24090/mnh.v12i2.1361

Zainal Arifin, "Tantangan Membentuk Keluarga Sakinah Pada Generasi Milenial”, Jurnal Wahana Islamika 6 (2), 2020.

DOI https://doi.org/10.5281/wahanaislamika.v6i2.91 


\section{Peraturan perundang-undangan}

Undang-Undang No. 1 Tahun 1974 tentang Perkawinan.

Undang-Undang Nomor 23 Tahun 2002 tentang Perlindungan Anak.

Instruksi Presiden Republik Indonesia No. I Tahun 1991 tentang Kompilasi

Hukum Islam (KHI). 